\title{
Commentary: Transdiaphragmatic omental flap without thoracotomy for bronchopleural fistula
}

\author{
Paula A. Ugalde Figueroa, MD, ${ }^{\mathrm{a}}$ and Benny Weksler, $\mathrm{MD}^{\mathrm{b}}$
}

\footnotetext{
From the a Department of Respirology and Thoracic Surgery, Institut Universitaire de Cardiologie et de Pneumologie de Québec, Quebec City, Québec, Canada; and ${ }^{\mathrm{b}}$ Division of Thoracic Surgery, Department of Thoracic and Cardiovascular Surgery, Allegheny General Hospital, Pittsburgh, Pa.

Disclosures: Dr Ugalde is a speaker for Medtronic, Johnson \& Johnson, and AstraZeneca. Dr Weksler is a proctor for Intuitive Surgery and a speaker for AstraZeneca.

Received for publication Feb 9, 2019; accepted for publication Feb 11, 2019; available ahead of print March 20, 2019.

Address for reprints: Paula A. Ugalde Figueroa, MD, Division of Thoracic Surgery, Institut Universitaire de Cardiologie et de Pneumologie de Québec, 2725 Chemin Ste-Foy, Quebec City, Quebec G1 V4G5, Canada (E-mail: paula.ugalde@criucpq.ulaval.ca).

J Thorac Cardiovasc Surg 2019;157:e417

$0022-5223 / \$ 36.00$

Copyright (C) 2019 by The American Association for Thoracic Surgery

https://doi.org/10.1016/j.jtcvs.2019.02.052
}

Historically, the incidence of bronchopleural fistula after lobectomy has been reported to be $1 \% .^{1}$ A more modern series that was based on the large French database Epithor has reported an incidence of postlobectomy bronchopleural fistula of $0.5 \% .^{2}$ Large minimally invasive lobectomy series have reported the incidence as varying from $0 \%$ to $0.6 \%{ }^{3,4}$ There are several possible treatment options for patients with postlobectomy bronchopleural fistula, but most commonly a muscle flap or an omental flap is used to obliterate the pleural space and reinforce the bronchial closure. ${ }^{5}$ Usually, a thoracotomy is required for muscle flaps, and a laparotomy (or laparoscopy) and a thoracotomy are required for the omental flap. Patients with bronchopleural fistula are often sick and debilitated, and they may not tolerate a thoracotomy well.

In this issue of the Journal, David and colleagues ${ }^{6}$ present the case of a patient who had a bronchopleural fistula develop as a result of complete dehiscence of the bronchial stump after a robotically assisted right lower lobectomy. As is often the case, this was a patient with multiple comorbidities, including synchronous head and neck cancer, coronary artery disease, and diabetes. In this case, the patient was clinically well, and the postlobectomy cavity was relatively clean. David and colleagues ${ }^{6}$ performed a laparotomy and created an omental flap that was based on the right gastroepiploic arcade. The diaphragm was then incised (phrenotomy), and the omentum was placed through the diaphragmatic defect into the thoracic cavity, where it completely filled the postlobectomy cavity and sealed the bronchial stump. The diaphragm was then stitched to the omentum to close the gap. The patient did well, and bronchoscopy 14 months later showed a closed bronchial stump.

The approach of David and colleagues ${ }^{6}$ to postlobectomy bronchopleural fistula is courageous, because the potential for future diaphragmatic hernias is unknown. It may, however, benefit patients who are very sick and might not

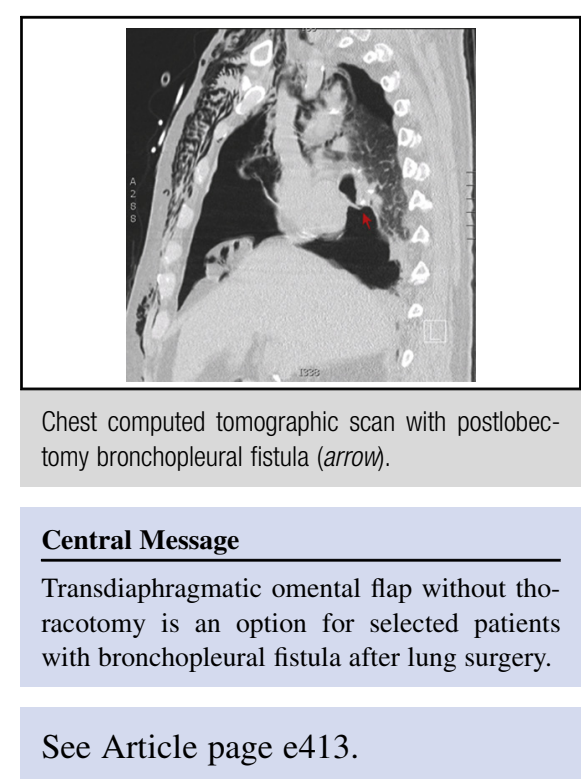

tolerate a major thoracic procedure. In the reported case, David and colleagues ${ }^{6}$ used the transdiaphragmatic flap for a lower lobe fistula, and it is likely that this approach would be more difficult for fistulas occurring after upper lobectomies. In addition to the potential for a diaphragmatic hernia, there is a theoretic risk of contaminating the peritoneal cavity if the pleural cavity is contaminated. In the reported case, the pleural cavity was clean, but often it is not. We believe that some caution is merited, because it is unknown how safe and how effective this procedure will be in a larger and more varied patient population. This may, however, be an attractive approach in the treatment of selected patients with lower lobe bronchopleural fistula.

\section{References}

1. Vester SR, Faber LP, Kittle CF, Warren WH, Jensik RJ. Bronchopleural fistula af ter stapled closure of bronchus. Ann Thorac Surg. 1991;52:1253-7; discussion 1257-8.

2. Pforr A, Pagès PB, Baste JM, Thomas P, Falcoz PE, Lepimpec Barthes F, et al. A predictive score for bronchopleural fistula established using the French database Epithor. Ann Thorac Surg. 2016;101:287-93.

3. Onaitis MW, Petersen RP, Balderson SS, Toloza E, Burfeind WR, Harpole DH Jr, et al. Thoracoscopic lobectomy is a safe and versatile procedure: experience with 500 consecutive patients. Ann Surg. 2006;244:420-5.

4. McKenna RJ Jr, Houck W, Fuller CB. Video-assisted thoracic surgery lobectomy: experience with 1,100 cases. Ann Thorac Surg. 2006;81:421-5; discussion 425-6.

5. Cooper WA, Miller JI Jr. Management of bronchopleural fistula after lobectomy Semin Thorac Cardiovasc Surg. 2001;13:8-12.

6. David CH, D'Journo XB, Dutau H, Thomas PA. Transdiaphragmatic plombage omentoplasty without thoracotomy for post-lobectomy bronchial fistula. J Thorac Cardiovasc Surg. 2019;157:e413-5. 